\title{
Development a new costing structure using time driven activity-based costing for palm oil plantation
}

\author{
S.N.A.M.Zaini ${ }^{1^{*}}$ and M.Y.Abu ${ }^{1}$ \\ ${ }^{I}$ Faculty of Manufacturing and Mechatronic Engineering Technology, Universiti Malaysia Pahang, 26600, \\ Pekan, Pahang, Malaysia \\ *Email:areena5582@gmail.com
}

\begin{abstract}
Palm oil is one of the world's most traded farming commodities. The Malaysian palm oil industry is without a doubt to the nation's pride. However, there are few problems currently happen in this plantation which are no establishment of time equation to interpret deviation of activities, the rate establishment did not properly illustrate the correlation between supplied resources and practical capacity, and the manager did not have a tool to monitor the unused capacity. The aim of this work is to develop a new costing structure for a better accuracy specifically at nursery. Time-driven activitybased costing (TDABC) was applied because it can effectively measure the time efficiency, accurately identifies the idle capacity and separately lists the used and unused capacity. It also provides more comprehensive understanding of practical resources and its associated costs while measuring processes and encouraging quality improvement. The plantation located at Pahang which has three main divisions and this work was focusing on nursery only. This work found that a precise process mapping for nursery was developed to understand their specific sequence which contributes to time equations. Subsequently, the total used capacity and capacity cost rate (CCR) for pre-nursery was successfully developed with 98220 minutes and $0.168 \mathrm{RM} /$ minute respectively. Eventually, the manager can observe that actually the unused capacity was 37515.31 min which can be used to systematically develop the capacity planning on the pre-nursery.
\end{abstract}

Indexed Terms- Palm oil plantation, time-driven activity-based costing, capacity cost rate, time equation, traditional cost accounting.

\section{INTRODUCTION}

In 2018, Malaysia's oil palm industry showed an unfavourable performance as against the 2017 performance. Fresh fruit bunch yields, crude palm oil production and palm oil exports decreased while imports of palm oil increased and palm oil stocks closed higher. Higher carry-over stocks, higher palm oil imports and lower exports pushed palm oil stocks to reach above 3 million tonnes as at the end of December 2018. Technology adoption can be observed throughout the different areas of research and it is clearly driving agricultural and process improvement and simultaneously ensuring the sustainable development of the industry [1]. [2] stated that top management, quality control and organizational capabilities are really important towards sustainable services on green practices. Somehow, adoption happened due to the improper costing structure with lack of financial understanding. traditional standard cost systems were popular until the 1980s became less useful because the direct labour content of products declined. [3] suggested a new economic model should be introduced to create high income to society, sustainability and inclusiveness which lead to better quality of life. The application of the traditional method based on a single basis such as direct working hours contributes less accurate and simply no longer reflected economic reality. Suppose that the costs of the activities carried out and then orders, products and customers to develop a better costing structure. Activity based costing (ABC) is a costing methodology proposed by Cooper and Kaplan assumes that multiple products consume the same activities and these activities require resources in different proportions [4]. It provides more accurate 
estimation of the cost of product or service especially when it is composed of a portion of peopleoriented activities and activities in a particular centre [5]. It also consists of mapping processes and identifying activities that add value to the process, the analysis of cost allocation to these activities and the use of developed cost drivers [6]. This approach provides an accurate process mapping especially for a business process analysis of the organization and its application is quite relevant in settings where the largest portion of costs is allocated to skilled work force [7]. ABC is an appropriate methodology to understand the costs in high-complexity systems but since the method is people-oriented drivers, it is slow in implementation and hard to regularly update [8]. On the other hand, TDABC is a modified ABC which directly assigns the costs of resources from cost objects through capacity cost rate. The basic principle of this methodology is that it converts cost drivers into time equations, which represent time required to perform a given activity [9]. The method revealed few advantages to respective applications. [10] had hypothesised that understanding the sources of cost variation across the three sites may reveal opportunities for cost reduction which does not jeopardise patient outcomes. [11] confirmed that TDABC may help managers focus on value-adding activities and limit nonvalue-adding ones, something that is greatly called for in any business and increased decision-making power when it comes to accepting protocol deviations. [12] agreed that TDABC method can help decision-makers to obtain the optimal configuration for product mix. [13] concluded that the TDABC simplifies the costing process by skipping possible interviews or surveys conducted with employees in order to allocate the resource costs. In this way, TDABC avoids $\mathrm{ABC}$ 's expensive, time-consuming and subjective activity monitoring task. A survey has been conducted on the application of TDABC from 2010 until 2018 which consist of 56 published journals as shown in Fig. 1. There are three main sectors which are healthcare, industrial and library that applying TDABC as their cost accounting system. It is proven that there is no work done using TDABC system in the plantation based on the previous research survey.

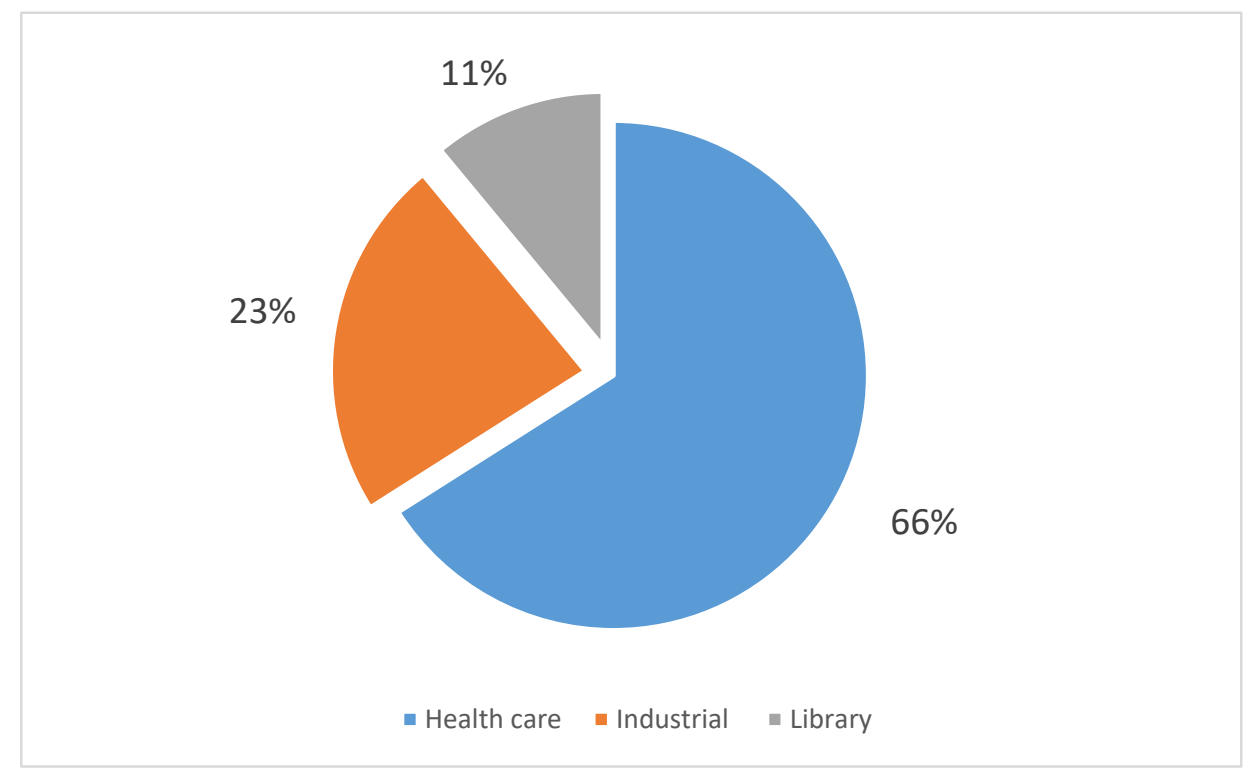

Figure 1: Application fields that using TDABC system

According to [14], the strengths of TDABC was divided into support operational improvement, inform reimbursement policy, accurately capture the cost of care, manage the complexity inherent, more efficient and simpler than traditional $\mathrm{ABC}$. Thus, this work used the elements to convince more the research gap from the published work from 2010 until 2018 as shown in Fig. 2. 


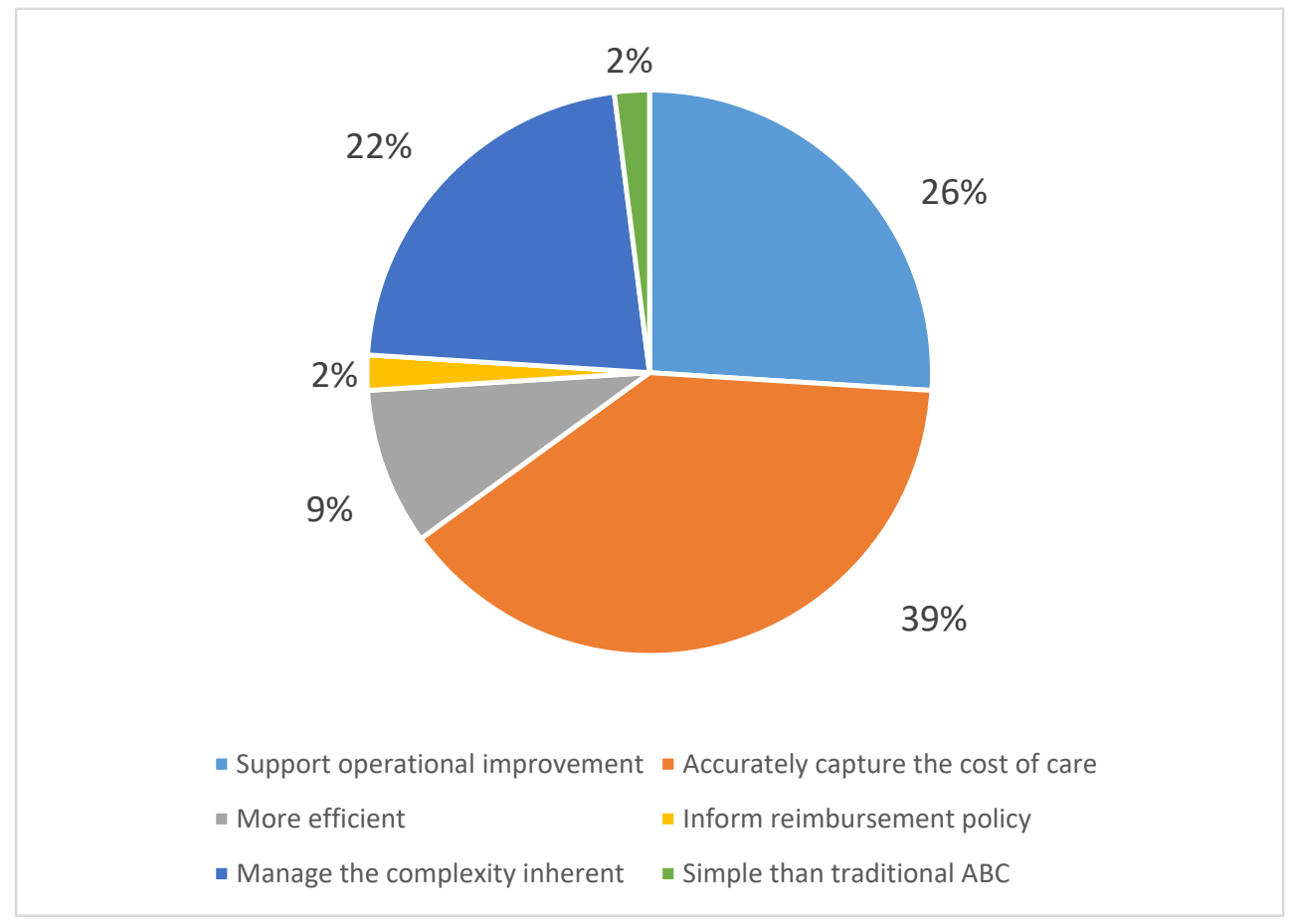

Figure 2: Distribution chart of reasons for applying TDABC

According to Fig. 2, element of accurately capture the cost of care has the highest number of percentages with $39 \%$ in terms of reason to apply TDABC. Then, followed by support operational improvement with $26 \%$, manage the complexity inherent with $22 \%$, more efficient with $9 \%$ and simple than traditional $\mathrm{ABC}$ and informs reimbursement policy shared the same percentage with $2 \%$. This work was focussing on the element of more efficient because the current plantation really needs a new with precise costing structure. By surveying few critical works, [13] accessed all important elements of TDABC such as process mapping, capacity cost rate, time equation and forecasting. The study is solely focused in industrial service. Other than that, [15] and [16] had undergoing studies in industrial service by using only two elements which are capacity cost rate and time equation. [16], [17], [14] and [18] focussed on process mapping, capacity cost rate and time equation in healthcare service. Work by [19] also did similarly but applied the TDABC in library service. [20] and [21] solely used capacity cost rate to find the true cost in library sector. In a nutshell, this total research gap was constructed compliance to the current data as it was based on legit research findings.

\section{METHODOLOGY}

This work implemented the case study at plantation located in Muadzam Shah, Pahang. It has three main divisions and this work focussed at Simpai division 1 where all the data has been collected. Then the division 1 was categorized into three main areas which are mature, immature and replanting area. In the mature area, all plants were planted since year 1990 and 1991, for the immature area were planted in year 2015 and 2016, and the youngest plants which planted in the year 2017 were located in replanting area. Table 1 shows the specific area of plantation with total number of acres in Simpai division 1.

There are many activities and sub-activities take place started from received the ordered seeds until the fresh fruits are harvested and transported to the factory for crude palm oil production process. There are three main activity centres where all data and information were collected from. It started with nursery, followed by replanting field and ended at ramp. Since this work was concerning on costing 
development, a data collection with respect to all activities are very important. Table 2 shows the cost of expenditure in nursery by specific activities which covers from January till July 2018. This is very important to calculate the cost of capacity supplied.

Table 1: Specific area of Simpai division 1

\begin{tabular}{|c|c|c|c|c|c|}
\hline & \multicolumn{2}{|c|}{ Mature } & \multicolumn{2}{|c|}{ Immature } & $\begin{array}{c}\text { Re-planting / } \\
\text { Immature }\end{array}$ \\
\hline & P90 A1 & P91 D1 & PR15 A1 & PR16 B1 & PR17 C1 \\
\hline & P90 A2 & P91 D2 & PR15 A2 & PR16 B2 & PR17 C2 \\
\hline & P90 A3 & P91 D3 & PR15 A3 & PR16 B3 & PR17 C3 \\
\hline & P90 A4 & P91 D4 & PR15 A4 & PR16 B4 & \\
\hline & P90 A5 & P91 D5 & & PR16 B5 & \\
\hline & P90 A6 & & & & \\
\hline & P90 A7 & & & & \\
\hline & P90 A8 & & & & \\
\hline Actual acre: & 894.2 & 651 & 531 & 560 & 449 \\
\hline TOTAL: & \multicolumn{2}{|c|}{1545.2} & \multicolumn{2}{|c|}{1091} & 3085.2 \\
\hline
\end{tabular}

Table 2: Expenditure cost in nursery by activities

\begin{tabular}{|c|c|c|c|c|c|c|c|}
\hline Month & Jan & Feb & March & April & May & June & July \\
\hline \multicolumn{8}{|l|}{ Activity } \\
\hline \multicolumn{8}{|l|}{$\begin{array}{l}\text { Germinated } \\
\text { seeds }\end{array}$} \\
\hline Water pump & & & & & 1590.84 & 2537.5 & 60 \\
\hline Generator set & & & 396 & & 3391.4 & & \\
\hline $\begin{array}{l}\text { Main/pre } \\
\text { nursery }\end{array}$ & 16307.57 & 1600.56 & 6191.24 & 2293.17 & 4910.98 & 8366.3 & 8947.4 \\
\hline \multicolumn{8}{|l|}{ Diesel } \\
\hline $\begin{array}{l}\text { Chemical } \\
\text { (weeding) }\end{array}$ & 5507.75 & & & 3900.8 & & & 2208 \\
\hline Chemical (P\&D) & & & 344.5 & & & & 2861 \\
\hline Fertilizer & & & 20352 & & 2332 & & \\
\hline Planting tray & 16536 & & & & & & \\
\hline Polybag & 27030 & & & & & & \\
\hline \multicolumn{8}{|l|}{ Road upkeep } \\
\hline Grand total & 65381.32 & 1600.56 & 27283.74 & 6193.97 & 12225.22 & 10903.8 & 14076.4 \\
\hline Cost/seedling & 0.49 & 0.01 & 0.21 & 0.05 & 0.1 & 0.17 & 0.23 \\
\hline Total (RM) & 65959.88 & 1278.13 & 26733.84 & 6096.7 & 11792.4 & 10973.16 & 140738.84 \\
\hline
\end{tabular}

Table 3 shows the total cost of nursery which covers from January till July 2018. This data is very important because the cost is a combination of labor and expenditure which supported the cost of capacity supplied. Then, it will generate the capacity cost rate for each sub-activity in nursery to produce more accurate the final cost.

There are 4 important elements of TDABC with specifically twelve steps to produce the new costing structure as shown in Fig. 3. The flow is divided into process mapping, time equation development, capacity cost rate establishment and forecast analysis. 
Table 3: Total cost of nursery

\begin{tabular}{ccccccc}
\cline { 3 - 7 } & & \multicolumn{2}{c}{ Labor } & \multicolumn{3}{c}{ Other } \\
\hline Month & Total seedling & RM/seedling & Total & RM/seedling & Total & TOTAL \\
\hline Jan & 134612 & 0.06 & 8076.72 & 0.49 & 65959.88 & 74036.60 \\
Feb & 127813 & 0.1 & 12781.3 & 0.01 & 1278.13 & 14059.43 \\
March & 127304 & 0.11 & 14003.44 & 0.21 & 26733.84 & 40737.28 \\
April & 121934 & 0.14 & 17070.76 & 0.05 & 6096.7 & 23167.46 \\
May & 117924 & 0.13 & 15330.12 & 0.1 & 11792.4 & 27122.52 \\
June & 64548 & 0.22 & 14200.56 & 0.17 & 10973.16 & 25173.72 \\
July & 611908 & 0.32 & 195810.56 & 0.23 & 140738.84 & 336549.4 \\
\hline
\end{tabular}

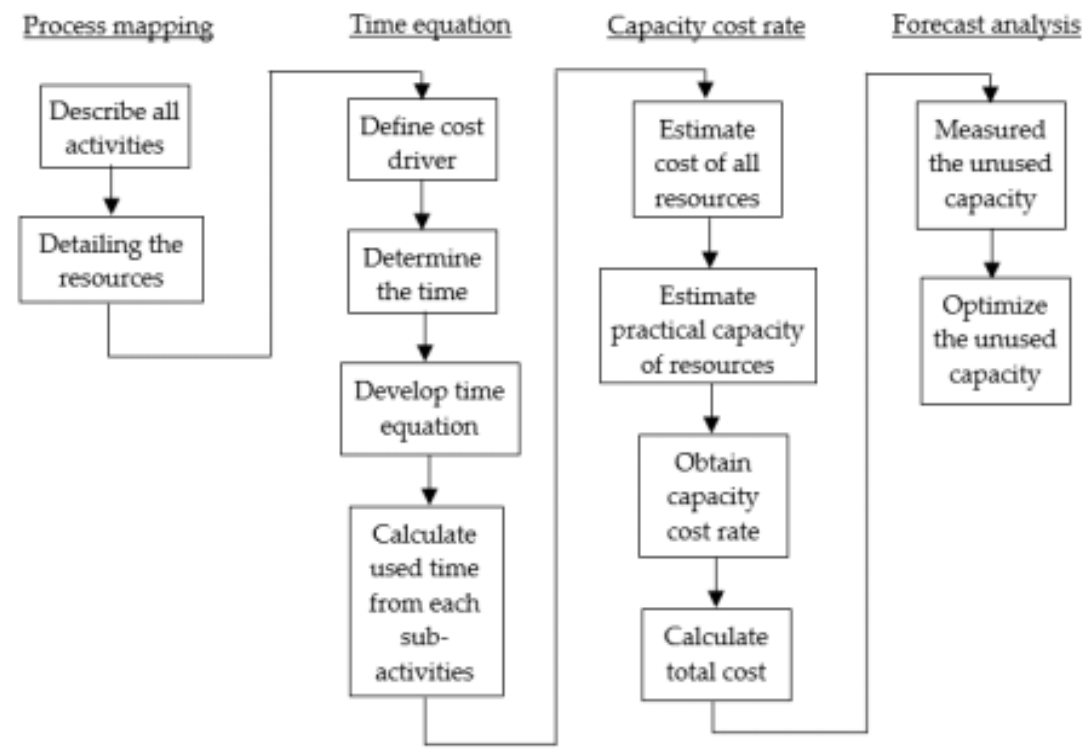

Figure 3: Flowchart of TDABC implementation

Process mapping identified all the activities and sub-activities related to palm oil production specifically at Simpai division 1 and detailing all possible resources. Then, time equation is developed by identifying their cost driver which directly proportional to the activities cost. Establishment the capacity cost rate is achieved by estimating all the capacity been supplied and determining the practical capacity currently used on the production. Finally, the forecasting is happened by measuring the unused capacity with respect to time and expenses as basis to optimization stage.

\section{RESULT AND DISCUSSION}

\subsection{Process mapping}

This element is very important to identify every single activity that influence to the final cost. Detail the activities indicates better accuracy to real cost and resources used. Thus, Fig. 4 shows a complete process from pre-nursery until transportation in Simpai division 1. This work divided the mapping into 3 centre for a better classification. The activity centre 1 focusing on nursery consists of two activities which are pre-nursery with five sub-activities and main nursery with seven sub-activities. The activity centre 2 focusing on replanting field process consists of eight activities which are chipping with one sub-activity, road and drain constructions with three sub-activities, planting with three sub-activities, 
manuring with one sub-activity, field maintenance with three sub-activities, pest and disease control with five sub-activities, harvesting with four sub-activities and internal transportation from field to ramp consists of one sub-activity. The activity centre 3 focusing on ramping process consists of one activity which is ramping with one sub-activity. This work found that by classifying the mapping into 3 centres actually eliminating waste in term of motion since centre 1 and 2 are quite far which means the development of time equation will not consider unnecessary activity.

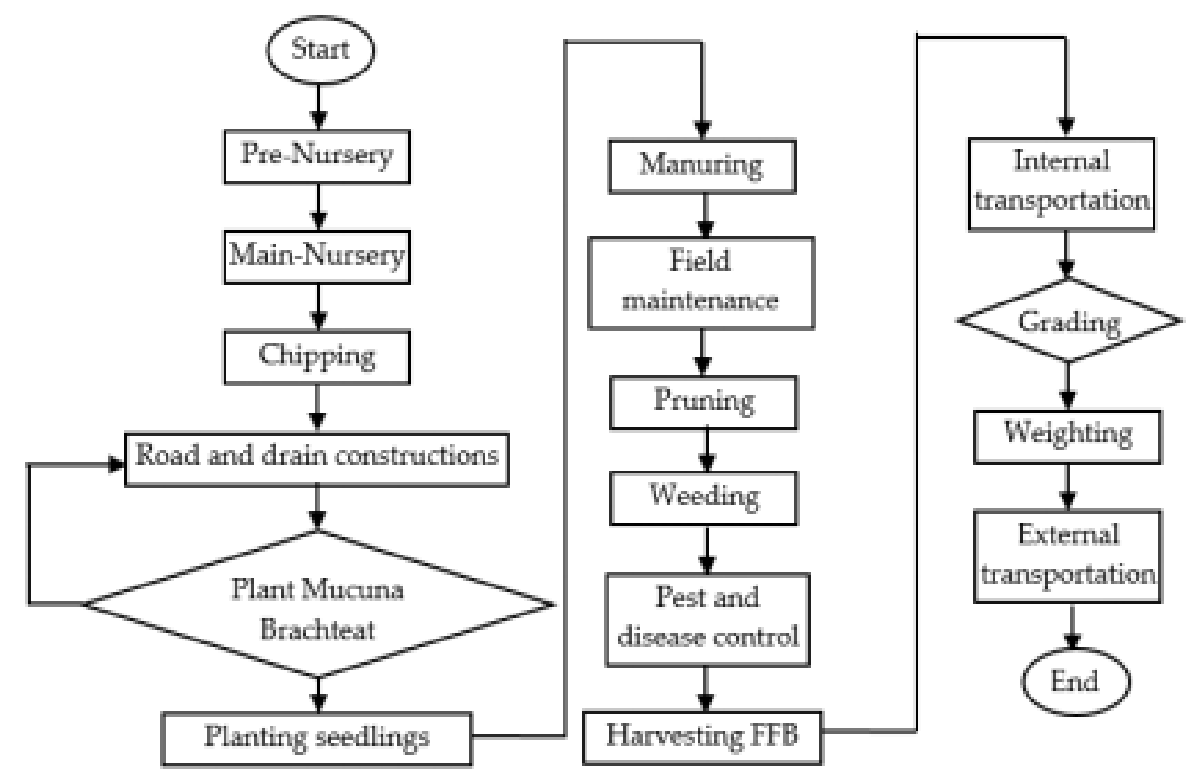

Figure 4: The work flow in Simpai division 1

In order to reduce the complexity with better understanding, this work only focused on nursery with pre-nursery and main nursery to develop the new costing structure. The pre-nursery started with HyPlug trays filling. HyPlug was filled within $2 \mathrm{~cm}$ of the container rim and placed in the nursery beds at least four weeks before the planting date to allow settling, topping up with soil and pre-planting irrigation. Then, planting the germinated seeds into the HyPlugs as soon as possible, preferably not later than a day after receipt. The seed is planted at $4 \mathrm{~cm}$ depth with the radicles pointing down and lightly covered with soil. The weeding process is taking over in the inter-bed paths and within the HyPlugs should be carried out monthly. Subsequently pesticides spraying and prophylactic spraying is done for better quality of pre-nursery. Pesticides may be mixed with foliar fertilizer mixtures in a single application. The culling process is very important to ensure that only the most uniform and vigorous palms that are likely to give the highest yields are planted in the field. The main types of undesirable palms on this sub-activity such as narrow due to grass leaf, rolled leaf, twisted leaf and crinkled leaf palms. This stage is carried out normally at month 2 and prior to transplanting the main nursery at around month 3 . After the pre-nursery was done, the main nursery will take over to sustain the plantation. It started with polybag filling whereby the necessary ploughing and harrowing of the soil must be done to provide loose friable soil which can directly filled into the bags. Filling of the polybags should commence at least a month prior to the transplanting. Transplanting from pre-nursery into large polybags means the detached seedling is placed into the large polybag which filled with soil firmly compacted around the root mass. In order to accomplish on manuring programme, the controlled or slow release fertilizer should be buried just below the soil surface for a better growth. Then, weeding process specifically is herbicides spraying on the ground and surrounding nursery area. At the same time pest and diseases control is achieved by pesticides spraying and prophylactic spraying. Culling process at this stage is carried out when seedlings are about seven and nine months old while the fronds of adjacent palms have 
not started to overlap. Finally, the seedlings are loaded onto lorries to transfer into the field. By having this process mapping, this work identified a lot of resources required with respect to materials, expanses, maintenance and workers to be considered into the cost of capacity supplied.

\subsection{Time equation}

Time equation is used to incorporate all the time needed to undertake all sub-activities in each activity centre within a single equation. To develop it, the time for main activity, the time for additional subactivities and its time driver are crucial to be considered. A time equation is needed to be developed to calculate the estimated used time. The estimated time for each activity was determined based on the motion and time study principles. For example, the average time taken for the transfer of harvested fruits from the fruit collection point to the ramp was found approximately to be 15 minutes per round. Each variable in the time equation is defined in Table 4 for nursery.

Table 4: Time taken for the nursery

\begin{tabular}{|c|c|c|c|}
\hline No. & Sub-Activities & Minute/round & \\
\hline \multicolumn{3}{|c|}{ Pre nursery } & \\
\hline 1. & HyPlug trays filling & 5 & \\
\hline 2. & Planting seeds into the HyPlugs & 1 & \\
\hline 3. & Hand weeding & 480 & \\
\hline 4. & $\begin{array}{l}\text { Pest and disease control (Pesticide, foliar and prophylactic } \\
\text { spraying) }\end{array}$ & 480 & \\
\hline \multirow[t]{2}{*}{5.} & Culling & 480 & \\
\hline & Total : & & 1446.00 \\
\hline & Main nursery & & \\
\hline 6. & Polybag filling & 2 & \\
\hline 7. & Transplanting from pre-nursery into large polybags & 2 & \\
\hline 8. & $\begin{array}{l}\text { Manuring programme based mainly on controlled/slow release } \\
\text { fertilizer }\end{array}$ & 420 & \\
\hline & Chemical weeding (Herbicide spraying) & 480 & \\
\hline 10. & $\begin{array}{l}\text { Pest and disease control (Pesticide, foliar and prophylactic } \\
\text { spraying) }\end{array}$ & 480 & \\
\hline & Culling & 480 & \\
\hline & $\begin{array}{l}\text { The seedlings are being loaded onto lorries/tractors to be } \\
\text { transported to the field. }\end{array}$ & 0.75 & \\
\hline & Total : & & 1864.75 \\
\hline & TOTAL: & & 3310.75 \\
\hline
\end{tabular}

From Table 4, the total time taken for every round for each activity in nursery can be observed respectively. The total time taken per round in activity 1, pre nursery is 1446 minutes while main nursery takes 1864.75 minutes. From both activities, it sums into a total of 3310.75 minutes for every single round per month. The time driver is depending on its activity characteristics which either needed or not to be multiplied together with the time activity. In this study, time equation needs to identify the used capacity (min/month) for each the sub-activities. The estimated capacity required by each activity was determined by quantifying the frequency of the activity in a month. By multiplying the amount of a given activity by the time spent doing it, one could calculate the total time spent on the activity. The volumes of cost-drivers for the activity centers are summarized in Table 5. 
Table 5: Volume of cost-drivers for nursery

\begin{tabular}{clc}
\hline Var. & \multicolumn{1}{c}{ Driver } & Quantity/month \\
\hline & \multicolumn{1}{c}{ Pre nursery } \\
\hline $\mathrm{X}_{1}$ & HyPlug trays filling (amount of HyPlug) & 16250 \\
$\mathrm{X}_{2}$ & Planting seeds into the HyPlugs (amount of seeds) & 16250 \\
$\mathrm{X}_{3}$ & Hand weeding (frequency/month) & 0.5 \\
$\mathrm{X}_{4}$ & $\begin{array}{l}\text { Pest and disease control (Pesticide, foliar and prophylactic spraying) } \\
\text { (frequency/month) }\end{array}$ & 0.5 \\
$\mathrm{X}_{5}$ & Culling (frequency/month) & 0.5 \\
\hline \multicolumn{1}{c}{ Main nursery } \\
\hline $\mathrm{X}_{6}$ & Polybags filling (amount of bag) & 3006.25 \\
$\mathrm{X}_{7}$ & Transplanting from pre nursery into large polybags (amount of bag) \\
$\mathrm{X}_{8}$ & Manuring programme based mainly on controlled/slow release fertilizer & 3006.25 \\
& (SRF) (rounds) & 0.25 \\
$\mathrm{X}_{9}$ & Chemical weeding (Herbicide spraying) (frequency/month) & 0.125 \\
$\mathrm{X}_{10}$ & $\begin{array}{l}\text { Pest and disease control (Pesticide, foliar and prophylactic spraying) } \\
\text { (frequency/month) }\end{array}$ & 0.25 \\
$\mathrm{X}_{11}$ & Culling (frequency/month) & 0.375 \\
$\mathrm{X}_{12}$ & The seedlings are being loaded onto lorries/tractors to be transported to \\
& the field. (rounds) & 3006.25 \\
\hline
\end{tabular}

During pre-nursery, ordered seeds need to be planted within two months after its arrival. For starting, 16250 from a total of 32500 HyPlug trays are being filled in order to plant the same amount of seeds. The treatment and control measures in this stage such as hand weeding, pest and disease control and culling take same frequency in a month which is 0.5 . This is because those three sub-activities have been applied on field once for every two months. Meanwhile, for main nursery, it takes eight months before the seedlings are sent to the replanting field. Polybag filling, transplanting from pre-nursery into large polybags, and finally the seedlings are being loaded onto lorries/tractors to be transported to the field required 3006.25 rounds in a month. The total amount of seedlings that being transferred from prenursery to main nursery is differ, which started with 32500 and end up with 24050 . This reduction is due to the standard evaluation from previous discovery, based on the culling rates and various losses. Manuring programme and pest and disease control undergoing 0.25 rounds/month as it only takes two cycles within eight months. Weeding or herbicide spraying demanded for 0.125 round as it required only once for all eight months. Lastly, culling in the main nursery need to have 0.375 rounds in a month as it demanded three cycles in every batch. Time equation is able to incorporate all the time needed to undertake all sub-activities in each activity centre as shown in equation (1).

$\mathrm{T}_{\mathrm{t}}=\beta_{0}+\beta_{\mathrm{i}} X_{\mathrm{i}}$

Where:

$\mathrm{T}_{\mathrm{t}}=$ the time needed to perform an activity (minute).

$\beta_{\mathrm{o}}=$ the standard time to perform the basic activity (minute).

$\beta_{\mathrm{i}}=$ the estimated time to perform the incremental activity (minute).

$\mathrm{X}_{\mathrm{i}}=$ the quantity of the incremental activity (time).

Table 4 was then multiplied by the relevant variables in Table 5 or cost-drivers to develop a complete time equation for nursery as shown in Table 6. 
Table 6: Time equations for sub-activities of the nursery

\begin{tabular}{cll}
\hline No. & Activities & Time Equations \\
\hline 1. & Pre nursery & $5 \mathrm{X}_{1}+\mathrm{X}_{2}+480 \mathrm{X}_{3}+480 \mathrm{X}_{4}+480 \mathrm{X}_{5}$ \\
2. & Main nursery & $2 \mathrm{X}_{6}+2 \mathrm{X}_{7}+420 \mathrm{X}_{8}+480 \mathrm{X}_{9}+480 \mathrm{X}_{10}+480 \mathrm{X}_{11}+0.75 \mathrm{X}_{12}$ \\
\hline
\end{tabular}

From Table 6, a complete time equation for the activity centre 1 was developed as shown in equation (2).

$\mathrm{T}_{\text {nursery }}=5 \mathrm{X}_{1}+\mathrm{X}_{2}+480 \mathrm{X}_{3}+480 \mathrm{X}_{4}+480 \mathrm{X}_{5}+2 \mathrm{X}_{6}+2 \mathrm{X}_{7}+420 \mathrm{X}_{8}+480 \mathrm{X}_{9}+480 \mathrm{X}_{10}+480 \mathrm{X}_{11}+$ $0.75 \mathrm{X}_{12}$

After the time equations for the activity centres were created, the time equation to calculate the total time spent in a cycle of palm oil's growth is presented in equation (3) as shown below.

$\mathrm{T}_{\text {total }}=\mathrm{T}_{\text {nursery }}+\mathrm{T}_{\text {replanting }}+\mathrm{T}_{\text {ramp }}$

Table 7 shows on how to get the actual used capacity for each sub-activities in all activity centers by multiplying the value of quantity or round needed for each sub-activities per month with total time taken for every round.

Table 7: Total used time for sub-activities of the activity center 1 nursery

\begin{tabular}{|c|c|c|c|c|}
\hline Var. & Driver & $\begin{array}{l}\text { Quantity/month } \\
\text { [1] }\end{array}$ & $\begin{array}{c}\text { Minute/round } \\
{[2]}\end{array}$ & $\begin{array}{l}\text { Used capacity } \\
(\mathrm{min} / \mathrm{month}) \\
{[1] \mathrm{x}[2]=[3]}\end{array}$ \\
\hline \multicolumn{5}{|c|}{ Pre nursery } \\
\hline $\mathrm{X}_{1}$ & HyPlug trays filling (amount of HyPlug) & 16250 & 5 & 81250 \\
\hline $\mathrm{X}_{2}$ & $\begin{array}{l}\text { Planting seeds into the HyPlug } \\
\text { (amount of seeds) }\end{array}$ & 16250 & 1 & 16250 \\
\hline $\mathrm{X}_{3}$ & Hand weeding (frequency/month) & 0.5 & 480 & 240 \\
\hline $\mathrm{X}_{4}$ & $\begin{array}{l}\text { Pest and disease control (Pesticide, foliar } \\
\text { and prophylactic spraying) (frequency/month) }\end{array}$ & 0.5 & 480 & 240 \\
\hline $\mathrm{X}_{5}$ & Culling (frequency/month) & 0.5 & 480 & 240 \\
\hline & Total: & & & 98220 \\
\hline \multicolumn{5}{|c|}{ Main nursery } \\
\hline $\mathrm{X}_{6}$ & Polybag filling (amount of bag) & 3006.25 & 2 & 6012.5 \\
\hline $\mathrm{X}_{7}$ & $\begin{array}{l}\text { Transplanting from pre-nursery into large } \\
\text { polybags (amount of bag) }\end{array}$ & 3006.25 & 2 & 6012.5 \\
\hline $\mathrm{X}_{8}$ & $\begin{array}{l}\text { Manuring programme based mainly on } \\
\text { controlled/slow release fertilizer (SRF) }\end{array}$ & 0.25 & 420 & 105 \\
\hline $\mathrm{X}_{9}$ & $\begin{array}{l}\text { Weeding (Herbicide spraying) } \\
\text { (frequency/month) }\end{array}$ & 0.125 & 480 & 60 \\
\hline $\mathrm{X}_{10}$ & $\begin{array}{l}\text { Pest and disease control (Pesticide, foliar } \\
\text { and prophylactic spraying) } \\
\text { (frequency/month) }\end{array}$ & 0.25 & 480 & 120 \\
\hline $\mathrm{X}_{11}$ & Culling (frequency/month) & 0.375 & 480 & 180 \\
\hline $\mathrm{X}_{12}$ & $\begin{array}{l}\text { The seedlings are being loaded onto } \\
\text { lorries/tractors to be transport to the } \\
\text { field. (rounds) }\end{array}$ & 3006.25 & 0.75 & 2254.69 \\
\hline & Total: & & & 14744.69 \\
\hline & TOTAL: & & & 112964.69 \\
\hline
\end{tabular}


According to Table 7, the total used capacity for pre nursery and main nursery are 98220 and 14744.69 respectively. The actual time spent (used capacity) on this activity center per month was determined by substituting the volume of cost-drivers from Table 5 with equation (2) as follow.

The actual time spent (used capacity) in activity center 1 , nursery $=(5 \times 16250)+(1 \times 16250)+(480 \times 0.5)$ $+(480 \times 0.5)+(480 \times 0.5)+(2 \times 3006.25)+(2 \times 3006.25)+(420 \times 0.25)+(480 \times 0.125)+(480 \times 0.25)+$ $(480 \times 0.375)+(0.75 \times 3006.25)=112964.69$ minutes.

\subsection{Capacity cost rate}

If the used resources all fall under the same activity, costs can be allocated directly to that activity. However, if resources are used for several activities, an allocation method based on the appropriate cost-driver has to be used. In this study, the researchers allocated based on the types of resource used for each activity, these being divided into two groups: (i) labor costs and (ii) the cost of equipment, machinery and other equipment. All workers in plantation are due to receive basic salary which is RM1300 except for workers in nursery, ramp, harvester and who are involved with transportation of FFB. The resources costs in nursery are based on the seedlings rate for each month. For those who are assigned to do chemical spraying, he will receive an additional RM0.01 for every palm. For harvester and loader, they will receive their wages based on the total tones of FFB they work on which is RM30/ton for harvester and RM6/ton for loader. Estimated costs of all the resources used in each of the sub-activities described above are summarized in Table 8.

Table 8: Labor, equipment, machinery and other equipment costs within the nursery

\begin{tabular}{|c|c|c|c|c|}
\hline No. & Sub-Activities & Labor costs & Overheads & $\begin{array}{c}\text { Cost of resources } \\
\text { supplied }\end{array}$ \\
\hline \multicolumn{5}{|c|}{ Pre nursery } \\
\hline & HyPlug trays filling & 11700 & 2958.15 & 14658.15 \\
\hline & Planting seeds into the HyPlug trays & 2925 & 1467.05 & 4392.05 \\
\hline & Hand weeding & 325 & - & 325 \\
\hline & $\begin{array}{l}\text { Pest and disease control (Pesticide, foliar and } \\
\text { prophylactic spraying) }\end{array}$ & 650 & - & 650 \\
\hline & Culling & 325 & - & 325 \\
\hline & Total: & 15925 & 4425.20 & 20350.20 \\
\hline \multicolumn{5}{|c|}{ Main nursery } \\
\hline & Polybag filling & 1950 & 4810 & 6760 \\
\hline & $\begin{array}{l}\text { Transplanting from pre-nursery into large } \\
\text { polybags }\end{array}$ & 1950 & 1467.05 & 3417.05 \\
\hline & $\begin{array}{l}\text { Manuring programme based mainly on } \\
\text { controlled/slow release fertilizer (SRF) }\end{array}$ & 273.81 & - & 273.81 \\
\hline & Weeding (Herbicide spraying) & 273.81 & 986.05 & 1259.86 \\
\hline & $\begin{array}{l}\text { Pest and disease control (Pesticide, foliar and } \\
\text { prophylactic spraying) }\end{array}$ & 273.81 & - & 273.81 \\
\hline 11. & Culling & 243.75 & - & 243.75 \\
\hline \multirow{3}{*}{\multicolumn{2}{|c|}{$\begin{array}{l}\text { 12. The seedlings are being loaded ontc } \\
\text { lorries/tractors to be transported to } \\
\text { Total: } \\
\text { TOTAL: }\end{array}$}} & 975 & - & 975 \\
\hline & & 5940.18 & 7263.10 & 13203.28 \\
\hline & & 21865.18 & 11688.30 & 33553.48 \\
\hline
\end{tabular}

During pre-nursery, the plantation requires eight employees at a cost of RM1950 for each as nursery's basic salary in that month. This is because all resources costs in nursery are depending on the rate of seeds. Six workers are assigned at HyPlug trays filling and another two at planting seeds into HyPlug trays. Besides, one of the two will do hand weeding, culling, and pest and disease control. That worker 
will receive an extra payment which is RM0.01 for each palm he sprayed on for pest and disease control. All workers received a basic salary which is RM1950 but only a worker who is doing chemical spraying will be given an additional of RM325 for 32500 seeds. Overall, it is giving a total of RM15925 for labor costs. The expenditure costs in pre nursery are from HyPlug trays and seeds, giving a total of RM4425.20 per month. This means the total costs of this activity is RM18075.20. During main nursery, it requires three employees at a cost of RM1950 each per month, giving a total of RM5940.19, where there is a worker who received an additional of RM90.19 for manuring, herbicide spraying and pest spraying for 3006.25 seedlings. The expenditure costs in pre nursery are from polybags, manuring and chemical weeding, giving a total of RM7263.10 per month. This means the total costs of this activity is RM11688.30. Practical capacity indicates the current practice with respect to the available resources to achieve the particular activity. The plantation's working hours are Monday to Saturday, 8:00 morning to 6:00 evening and on Sunday from 8:00 morning to 1:00 evening. The employees work an average of eight hours a day for Monday to Saturday basis (26 days a month) and five hours on Sunday (4 days a month). There are no deductions for breaks, training and maintenance from these working hours, meaning employees have an acceptable capacity of 13,680 minutes each per month. As an example using this equation for pre-nursery, the capacity cost rate (CCR) is RM20350.20/109440 minutes or RM0.168 per minute. Table 9 shows the summary of CCR for each activity for nursery.

Table 9: CCR of each sub-activity for the nursery

\begin{tabular}{|c|c|c|c|c|}
\hline No. & Sub-Activities & $\begin{array}{c}\text { Cost of all } \\
\text { resources supplied } \\
(\mathrm{RM} / \mathrm{month}) \\
{[1]}\end{array}$ & $\begin{array}{c}\text { Practical } \\
\text { capacity } \\
\text { (min/month) } \\
{[2]} \\
\end{array}$ & $\begin{array}{c}\text { Capacity cost } \\
\text { rate } \\
(\mathrm{RM} / \mathrm{min}) \\
{[1] /[2]=[3]}\end{array}$ \\
\hline \multicolumn{5}{|c|}{ Pre nursery } \\
\hline 1. & HyPlug trays filling & 14658.15 & 82080 & \\
\hline 2. & Planting seeds into the HyPlug & 4392.05 & 20520 & \\
\hline 3. & Hand weeding & 325 & 2280 & \\
\hline 4. & $\begin{array}{l}\text { Pest and disease control (Pesticide, foliar and } \\
\text { prophylactic spraying) }\end{array}$ & 650 & 2280 & \\
\hline 5. & Culling & 325 & 2280 & \\
\hline & Total: & 20350.20 & 109440 & 0.168 \\
\hline \multicolumn{5}{|c|}{ Main nursery } \\
\hline 6. & Polybag filling & 6760 & 13680 & \\
\hline & $\begin{array}{l}\text { Transplanting from pre-nursery into large } \\
\text { polybags }\end{array}$ & 3417.05 & 13680 & \\
\hline 8. & $\begin{array}{l}\text { Manuring programme based mainly on } \\
\text { controlled/slow release fertilizer (SRF) }\end{array}$ & 273.81 & 1710 & \\
\hline 9. & Weeding (Herbicide spraying) & 1259.86 & 1710 & \\
\hline 10. & Pest and disease control & 273.81 & 1710 & \\
\hline 11. & Culling & 243.75 & 1710 & \\
\hline \multirow[t]{3}{*}{12.} & The seedlings are being loaded onto & 975 & 6840 & \\
\hline & $\begin{array}{l}\text { lorries/tractors to be transported to the field. } \\
\text { Total: }\end{array}$ & 13203.28 & 41040 & 0.438 \\
\hline & TOTAL: & 33553.48 & 150480 & \\
\hline
\end{tabular}

From Table 9, the CCR in pre nursery and main nursery are 0.168 and 0.438 respectively. By having this rate as reference, the unused capacity can be measured directly. 


\subsection{Forecast analysis}

The planning capacity system breaks down into three steps which are determining service level requirements, analyzing current capacity and forecast for the future. Within this first step, it exists three stages: establishing workloads, determining the unit of work and setting service levels. Then, the current production schedule is studied to evaluate capacity to analyze each workload and system as a whole. As the final step, forecasting plan is made to know the amount of incoming work expected over the coming batches. As a result, the researcher proposed ways to reduce costs based on the analysis of capacity utilization; in order to increase production capacity and decrease waste costs. An example on how this might be done for palm oil plantation activity centres are described in Table 10.

Table 10: Analysis of capacity utilization in the palm oil plantation activity centre

\begin{tabular}{|c|c|c|c|c|c|c|c|}
\hline $\begin{array}{l}\text { Act. } \\
\text { Cent. }\end{array}$ & Activities & $\begin{array}{c}\text { Practical } \\
\text { capacity } \\
\text { (min/month) } \\
{[1]}\end{array}$ & $\begin{array}{c}\text { Used } \\
\text { capacity } \\
\text { (min) } \\
{[2]}\end{array}$ & $\begin{array}{c}\text { Unused } \\
\text { capacity } \\
\text { (min) } \\
{[3]=[1]-} \\
{[2]}\end{array}$ & $\begin{array}{c}\text { Capacity } \\
\text { cost rate } \\
\text { (RM/min) } \\
{[4]}\end{array}$ & $\begin{array}{l}\text { Waste } \\
\text { cost } \\
(\mathrm{RM}) \\
{[3] \times[4]}\end{array}$ & $\begin{array}{c}\text { Utilization } \\
\text { cost } \\
\text { (RM) } \\
{[2] \times[4]}\end{array}$ \\
\hline \multirow[t]{4}{*}{1} & Nursery & & & & & & \\
\hline & Pre-nursery & 109440 & 98220 & 11220 & 0.168 & 1884.96 & 16500.96 \\
\hline & $\begin{array}{l}\text { Main } \\
\text { nursery }\end{array}$ & 41040 & 14744.69 & 26295.31 & 0.438 & 11517.35 & 6458.17 \\
\hline & Total: & 150480 & 112964.69 & 37515.31 & & 13402.31 & 22959.13 \\
\hline \multirow[t]{10}{*}{2.} & Replanting & & & & & & \\
\hline & Chipping & 54720 & 48100 & 6620 & 0.130 & 860.6 & 6253 \\
\hline & $\begin{array}{l}\text { Road and } \\
\text { drain } \\
\text { constructions }\end{array}$ & 218880 & 216252.86 & 2627.14 & 0.113 & 296.87 & 24436.57 \\
\hline & $\begin{array}{l}\text { Planting } \\
\text { seedlings }\end{array}$ & 191520 & 218227.9 & -26707.9 & 0.271 & -7237.84 & 59139.76 \\
\hline & Manuring & 27360 & 1996.15 & 25363.85 & 5.137 & 130294.1 & 10254.22 \\
\hline & $\begin{array}{l}\text { Field } \\
\text { maintenance }\end{array}$ & 109440 & 71454.47 & 37985.53 & 0.222 & 8432.79 & 15862.89 \\
\hline & $\begin{array}{l}\text { Pest and } \\
\text { disease control }\end{array}$ & 41040 & 4730.2 & 36309.8 & 0.200 & 7261.96 & 946.04 \\
\hline & Harvesting & 284544 & 288600 & -4056 & 0.106 & -429.94 & 30591.6 \\
\hline & $\begin{array}{l}\text { Internal } \\
\text { Transportation } \\
\text { (field to ramp) }\end{array}$ & 2736 & 1503.15 & 1232.85 & 8.497 & 145.09 & 12772.27 \\
\hline & Total: & 0240 & 861881.55 & 68358.45 & & 139623.63 & 160256.35 \\
\hline \multicolumn{2}{|c|}{ TOTAL: } & 1080720 & 974846.24 & 105873.76 & & 153025.94 & 183215.48 \\
\hline
\end{tabular}

Having analyzed the plantation cost using TDABC, the researcher able to identify unused capacity which results in waste costs, as summarized in Table 10. It shows that within the replanting activity centre, it incurs the highest amount of waste costs, at RM139623.63. This is followed by the nursery activity centre, with waste costs of RM13402.31. It was found that the largest loss was from replanting activity centre on manuring sub-activity. Those two workers should be deployed on another activity, one that does not have sufficient work capacity such as in planting seedlings stage, as this will help to reduce the amount of unused capacity. The used capacity will affect the utilization cost and the unused capacity will result in the present of waste cost. Every activity centres have different CCR, so the rate to calculate the utilization and waste costs are varied. For example in nursery, it shows that the unused capacity is higher than the amount of the waste cost. In the other hand, in replanting stage it shows vice 
versa. The unused capacity is lower than its waste cost. From this graph, it shows that the replanting centre had the highest rate for every analysis compared to the other two activity centers in view of the fact that it consists the greatest number of processes. In this activity centre, the level of graphs for utilization and waste costs can be seen to have only little differences between them. Yet, in overall, utilization cost has the higher value which is RM160256.35 compared to the waste cost which is RM139623.6. Apart of that, in manuring process, the waste cost (RM130294.1) is higher than the utilization cost (RM10254.22). The manager needs to find solution to minimize the amount of waste cost such as by reducing the number of worker, reducing their working hour or fill in their spare time with other complex activity that needs extra manpower. The example of sub-activity that needs a large number of workers to overcome its shortage of manpower is in planting seedlings process. The provided practical capacity is 218227.9 minutes per month, but actually it requires an extra of 26707.9 minutes to achieve the target planned. This work discovered that TDABC able to identify total costs was consistent with the actual use of resources at the plantation industry. It was found that the cost of each activity is different due to the varying factors affecting the costs of resources and capacity. Complex activity takes longer time to accomplish and those that involve a lot of processes tend to be increase further. The results of this study have given the case study company a clear view on what they can improve in order to reduce waste costs and increase working capacity. The analysis has highlighted which activities add value and which activities are wasteful, as well as the difficulties to be found in the plantation process. By improving efficiency, resource waste can be reduced, particularly by optimizing practical capacity resources.

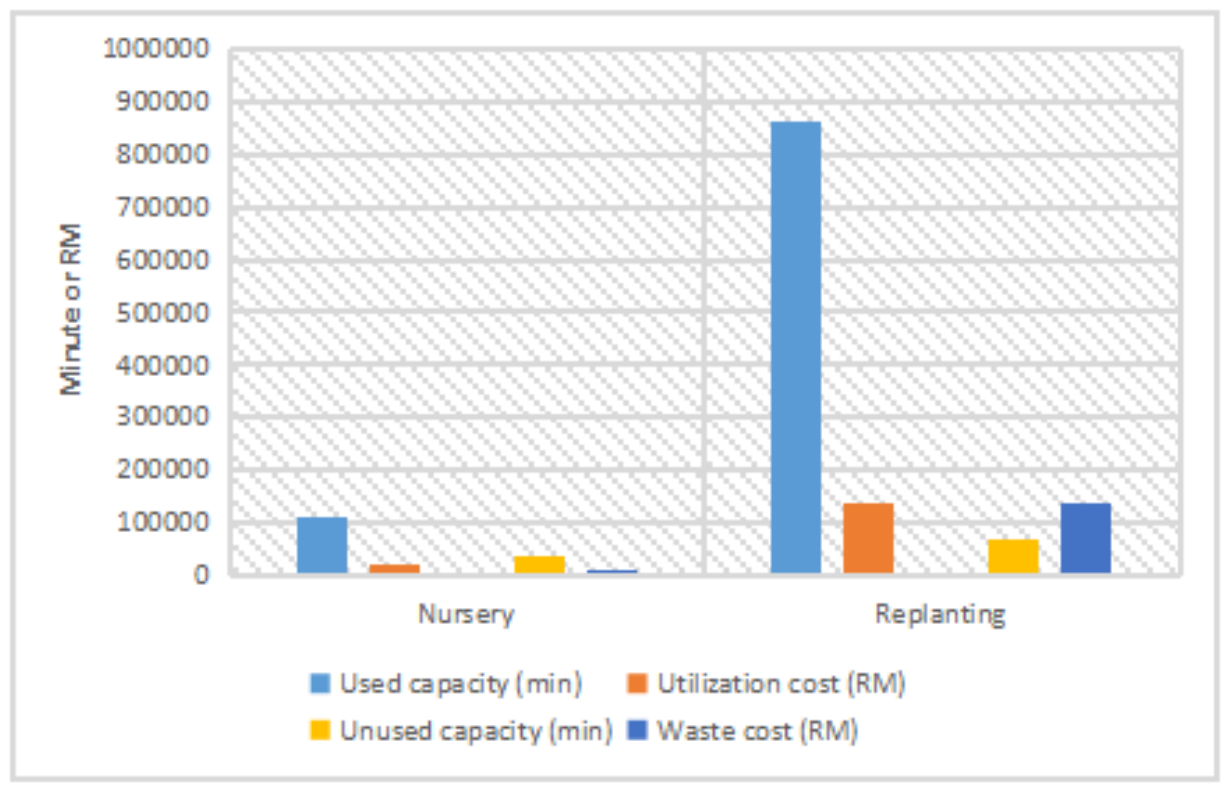

Figure 5: Graph of used capacity with utilization costs and unused capacity with waste costs

\section{CONCLUSION}

This work successfully developed the time equation through the process mapping for the nursery of palm oil plantation. All sub-activities in each activity centres are revealed to explain that the cost are directly proportional to them. Thus, the time equation constructed as $T_{\text {pre-nursery }}=5 \mathrm{X}_{1}+\mathrm{X}_{2}+480 \mathrm{X}_{3}+$ $480 \mathrm{X}_{4}+480 \mathrm{X}_{5}$ and from this equation, the total used capacity was 98220 minutes. Besides, the CCR for this process is $0.168 \mathrm{RM} /$ minute. Time equation and CCR can act as a tool for the manager to assess the unused capacity. From the value of unused capacity of 37515.31 min means the manager can reduce 
the resources for better saving. Therefore, the manager has a clear view to reduce production costs based on the analysis of capacity utilization in order to increase working capacity and decrease waste costs.

\section{ACKNOWLEDGEMENT}

The authors would like to thank to the Universiti Malaysia Pahang and Ministry of Education Malaysia for financial assistance under Research Grant project No. RDU190156 and FRGS/1/2018/TK03/UMP/02/34.

\section{REFERENCES}

[1] Kushairi A., Abdullah M.O-., Nambiappan B., Hishamuddin E., Bidin M.N.I.Z., Ghazali R., Subramaniam V., Sundram S. and Parveez G.K.A. "Oil palm economic performance in Malaysia and R\&D progress in 2018”, Journal of Oil Palm Research, 31(2), 165-194, 2019.

[2] Abdullah M.A., Chew B.C. and Hamid S.R. "The sustainable service management factors in high technology transport service industry", Journal of Advanced Manufacturing Technology, 101-113, 2017.

[3] Abdullah A. and Safari Z. "Industry collaboration program (ICP): empowering technology development for national economic growth", Journal of Advanced Manufacturing Technology, 159-172, 2017.

[4] Cooper R. and Kaplan R.S. "Profit priorities from activity-based costing", Harv Bus Rev, 69(3), 130-135, 1991.

[5] Abu M.Y., Jamaludin K.R. and Zakaria M.A. "Characterisation of activity-based costing on remanufacturing crankshaft", International Journal of Automotive and Mechanical Engineering, 14(2), 4211-4224, 2017.

[6] Kamil N.N.N.M. and Abu M.Y. "Integration of mahalanobis-taguchi system and activity-based costing for remanufacturing decision", Journal of Modern Manufacturing Systems and Technology, 1, 39-51, 2018.

[7] Abu M.Y., Nor E.E.M. and Rahman M.S.A. "Costing improvement of remanufacturing crankshaft by integrating mahalanobis-taguchi system and activity-based costing", IOP Conference Series: Materials Science and Engineering, 342, 1-10, 2018.

[8] Zheng C.W. and Abu M.Y. "Application of activity-based costing for palm oil plantation", Journal of Modern Manufacturing Systems and Technology, 2, 1-14, 2019.

[9] Zaini S.N.A.M. and Abu M.Y. "A Review on time-driven activity-based costing system in various sectors", Journal of Modern Manufacturing Systems and Technology, 2, 15-22, 2019.

[10] Erhun F., Mistry B., Platchek T., Milstein A., Narayanan V.G. and Kaplan R.S. "Time-driven activity-based costing of multivessel coronary artery bypass grafting across national boundaries to identify improvement opportunities: study protocol”, BMJ Open, 5(8), e8765, 2015.

[11] Ridderstrale M. "Comparison between individually and group-based insulin pump initiation by time-driven activity-based costing", J Diabetes Sci Technol, 11(4), 759-765, 2017.

[12] Tsai W.H., Chang J.C., Hsieh C.L., Tsaur T.S. and Wang C.W. "Sustainability concept in decision-making: carbon tax consideration for joint product mix decision", Sustainability, 8(12), 1-22, 2016.

[13] Zhuang Z.Y. and Chang S.C. "Deciding product mix based on time-driven activity-based costing by mixed integer programming", Journal of Intelligent Manufacturing, 28(4), 959-974, 2017.

[14] Keel G., Savage C., Rafiq M. and Mazzocato P. "Time-driven activity-based costing in health care: A systematic review of the literature", Health Policy, 121(7), 755-763, 2017.

[15] Wouters M. and Stecher J. "Development of real-time product cost measurement: A case study in a medium-sized manufacturing company", International Journal of Production Economics, 183, 235-244, 2017. 
[16] Anzai Y., Heilbrun M.E., Haas D., Boi L., Moshre K., Minoshima S. and Lee V.S. "Dissecting costs of CT study: application of TDABC (time-driven activity-based costing) in a tertiary academic center", Acad Radiol, 24(2), 200-208, 2017.

[17] Yu Y.R., Abbas P.I., Smith C.M., Carberry K.E., Ren H., Patel B. and Lopez M.E. "Time-driven activity-based costing: A dynamic value assessment model in pediatric appendicitis", $J$ Pediatr Surg, 52(6), 1045-1049, 2017.

[18] Yun B.J., Prabhakar A.M., Warsh J., Kaplan R., Brennan J., Dempsey K.E. and Raja A.S. "Timedriven activity-based costing in emergency medicine", Ann Emerg Med, 67(6), 765-772, 2016.

[19] Kont K.R. "How to optimize the cost and time of the acquisitions process?", Collection Building, 34(2), 41-50, 2015a.

[20] Kont K.R. and Jantson S. "Activity-based costing (ABC) and time driven activity-based costing (TDABC): Applicable methods for university libraries", Evidence Based Library and Information Practice, 6(4), 107-118, 2011.

[21] Kont K.R. "New cost accounting models in measuring of library employees' performance", Library Management, 33, 1/2, 50-65, 2011. 